\title{
Successful Treatment of Chronic Actinic Dermatitis with Dupilumab: A Case Report and Review of the Literature
}

\author{
Jiaoquan Chen \\ Huaping Li \\ Huilan Zhu
}

Department of Dermatology, Guangzhou Institute of Dermatology, Guangzhou, 510095, People's Republic of China
Correspondence: Huilan Zhu

Department of Dermatology, Guangzhou Institute of Dermatology, 56 Hengfu

Road, Guangzhou, 510095, People's

Republic of China

Email Zhlhuilan@I26.com

\begin{abstract}
Chronic actinic dermatitis (CAD) is a rather rare photosensitive disease characterized by a persistent eczematous eruption in sun-exposed sites. The pathogenesis of CAD has not been completely elucidated. The clinical treatment of CAD is still challenging and not standardized. Some patients with severe CAD have achieved satisfactory clinical results with dupilumab when conventional therapies have failed. We herein report the case of a 45 year-old male with severe CAD who responded rapidly to combined treatment with dupilumab (600 mg for 1 week, and then $300 \mathrm{mg}$ every 2 weeks) in 2 months. The patient experienced continuous improvement and no side effects from dupilumab (300 mg every month), having ceased other systemic medications. Dupilumab could be considered as an alternative or adjunctive treatment for CAD.
\end{abstract}

Keywords: chronic actinic dermatitis, dupilumab, treatment

\section{Introduction}

Chronic actinic dermatitis (CAD) is an immune-mediated photodermatosis characterized by pruritic eczematous lesions in areas exposed to the sun. ${ }^{1}$ Although the pathophysiology of CAD is not well known, it has been claimed that a Th1/Th2 dysbalance caused by suppressor $\mathrm{T}$ cells may play a role in the occurrence of $\mathrm{CAD}^{2}$ In some recalcitrant cases, conventional treatments based on photoprotection, topical steroids, and immunosuppressive agents are disappointing. Recently, dupilumab, a human monoclonal antibody developed for dampening Th2 signaling and inhibiting the effects of IL- 4 and IL-13, ${ }^{3}$ has shown promising results in small series and case reports on CAD. ${ }^{4-6}$ In this study, we present a 45 -year-old male with severe CAD who was successfully treated with dupilumab having had an unsatisfactory response to conventional treatments, and review all relevant cases.

\section{Case Report}

A 45-year-old Chinese male patient presented with a 3-year history of pruritic severe erythema on his face, neck, trunk, and upper extremities, specifically on sunexposed areas. The lesions were itchy with aggravation on sunlight exposure, especially in the summer season. He was diagnosed with severe atopic dermatitis (AD) and eczema, and did not respond to systemic corticosteroid hormone, methotrexate, and antihistamines, or to various topical treatments with corticosteroids and calcineurin inhibitors, prescribed at other hospitals, for more than 1 year. The 
patient had not taken any medication capable of inducing photosensitivity before the onset of chronic atopic dermatitis (CAD). The patient denied a previous history of allergic diseases (urticaria, $\mathrm{AD}$, allergic rhinitis, asthma, etc.), and no family history of allergic diseases was reported. Physical examination revealed severe erythema and papulae with crusted lesions, scratch marks, and diffuse pigmentation on his face and neck (Figure 1A). Besides, he was found to suffer from erythema, papulae, nodules, and pigmentation on his upper extremities. The skin biopsy was favorable for eczema with parakeratosis and mild spongiosis in the epidermis, as well as perivascular lymphocytes, fibrocollagenous and mononuclear cells in the dermis (Figure 2). Serum total immunoglobulin E was $293 \mathrm{IU} / \mathrm{mL}$ (normal 20-200 IU/mL) at his first visit. Eosinophils were in the normal range. The phototest (tested with an SUV1000 Solar UV simulator; Sigma, Shanghai) revealed markedly reduced minimal erythema dose (MED) both for UVB $\left(<26 \mathrm{~mJ} / \mathrm{cm}^{2}\right.$, normal MED $\left.>40 \mathrm{~mJ} / \mathrm{cm}^{2}\right)$ and UVA $\left(14 \mathrm{~J} / \mathrm{cm}^{2}\right.$, normal MED $>40 \mathrm{~mJ} /$ $\mathrm{cm}^{2}$ ). In light of the clinical presentation, pathological findings, and phototest, the diagnosis of CAD was made. In addition to strict sun avoidance and photoprotective garments, we prescribed oral ebastine $(10 \mathrm{mg} /$ day for 1 month), oral hydroxychloroquine ( $0.2 \mathrm{~g}$ /day for 1 month), and oral cyclosporine $\mathrm{A}$ (75 $\mathrm{mg} /$ day for $1 \mathrm{month})$. He was also treated topically with weak and strong steroid hormone ointments on his face and neck, and on his extremities, respectively. However, the patient's condition did not significantly improve, even after increasing the dose of cyclosporine A to $100 \mathrm{mg} /$ day (Figure 1B). After discussion with the patient and obtaining his consent, dupilumab was initiated with a loading dose of $600 \mathrm{mg}$ followed by $300 \mathrm{mg}$ every 2 weeks thereafter. The patient continued to take oral cyclosporine A $75 \mathrm{mg}$ every day and to apply topical treatment. Two months after the combined treatment, the patient was free from pruritus and achieved rapid and progressive improvement of the erythema and the papulae, although diffuse pigmentation remained (Figure 1C). Then, he stopped the oral cyclosporine A and received $300 \mathrm{mg}$ dupilumab every month, since the itchy erythema had improved dramatically

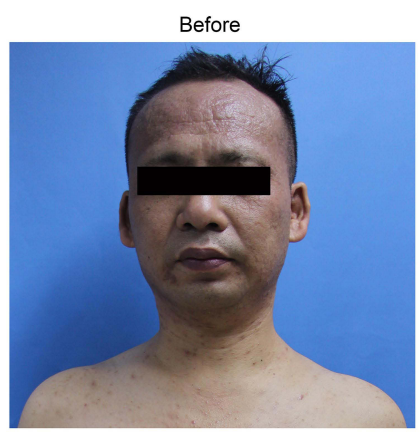

A

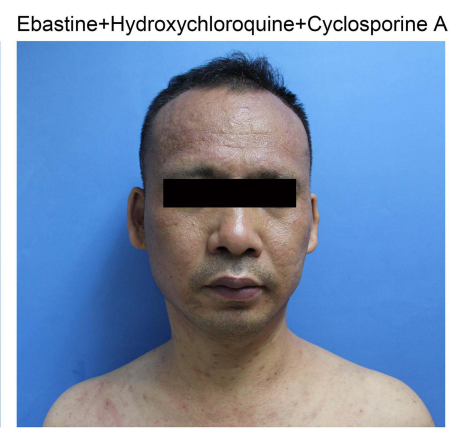

B

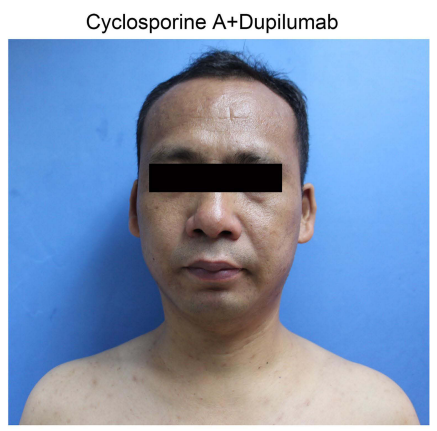

C

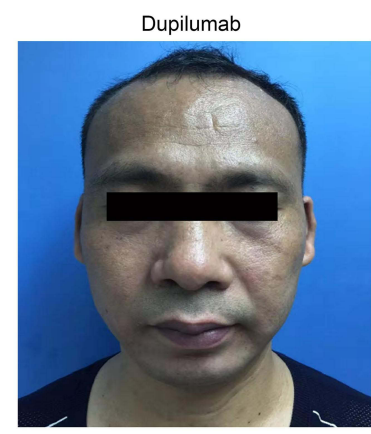

D

Figure I Clinical manifestations in a 45-year-old male with CAD before treatment (A), and following treatment with conventional therapies (B), treatment with cyclosporine A and dupilumab (C), and treatment with dupilumab (D).

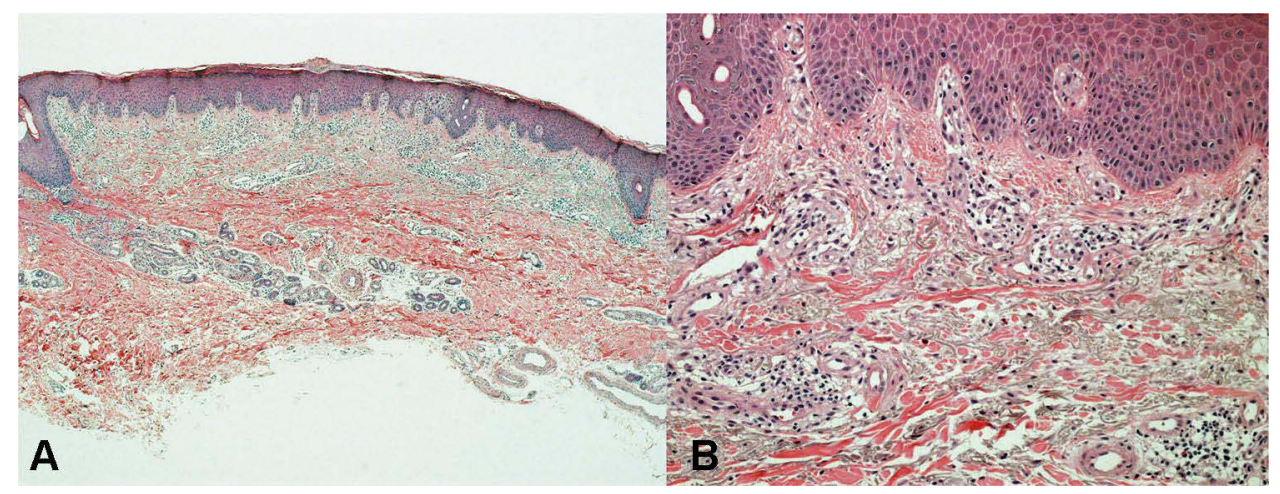

Figure 2 Parakeratosis and mild spongiosis in the epidermis, as well as perivascular lymphocytes, fibrocollagenous and mononuclear cells in the dermis. (Hematoxylin and eosin; magnifications: $($ A $) \times 40,(B) \times 400$.) 
(Figure 1D). His SCORing Atopic Dermatitis (SCORAD) and Dermatology Life Quality Index (DLQI) scores improved from 35.7 and 17, respectively, before treatment with dupilumab to 4.9 and 2, respectively, at his last visit. The patient is still under follow-up, with continuous improvement and no adverse effects.

\section{Discussion}

CAD is a rare and severe idiopathic photodermatosis commonly characterized by chronic persistent pruritic eczematous lesions in sun-exposed areas. ${ }^{7}$ An indispensable diagnosis in this patient was severe photo-aggravated dermatitis, as the hallmark of CAD is sensitivity to UVA,
UVB, and visible light. ${ }^{1}$ Although some etiological factors, such as phototoxicity, photoallergy, drug or chemical systemic photosensitivity, and polymorphic light eruption, have been proposed, ${ }^{8}$ the exact pathological mechanism of CAD has not been completely elucidated. However, a mechanism of delayed-type hypersensitivity to a UVinduced autoantigen or a contact allergy to exogenous allergens may be inferred. ${ }^{9}$ Ko et $\mathrm{al}^{2}$ found that Th1/Th2 dysbalance may be closely related to the onset of CAD.

As demonstrated by the present research, the therapeutic management of CAD is still challenging and not standardized. Given its pathophysiology and delayed hypersensitivity to an induced UV neoantigen, recommended treatments include

Table I Clinical Data on Dupilumab for the Treatment of Seven Patients with CAD, Including Our Single Case

\begin{tabular}{|c|c|c|c|c|c|c|c|}
\hline $\begin{array}{l}\text { Age } \\
\text { (Years)/ } \\
\text { Sex }\end{array}$ & $\begin{array}{l}\text { History } \\
\text { (Years) }\end{array}$ & Previous Treatment & Treatment & $\begin{array}{l}\text { Duration } \\
\text { of } \\
\text { Treatment }\end{array}$ & Response & Side Effects & References \\
\hline $45 / M$ & 3 & $\begin{array}{l}\text { Corticosteroids, } \\
\text { methotrexate, antihistamines, } \\
\text { corticosteroids, calcineurin } \\
\text { inhibitors }\end{array}$ & $\begin{array}{l}\text { Dupilumab } 600 \mathrm{mg} \text { for I } \\
\text { week and then } 300 \mathrm{mg} \\
\text { every } 2 \text { weeks/every } \\
\text { month, cyclosporine A, } \\
\text { topical therapies }\end{array}$ & 3 months & $\begin{array}{l}\text { Almost } \\
\text { complete }\end{array}$ & None & Present case \\
\hline $54 / M$ & NA & $\begin{array}{l}\text { Methotrexate, mycophenolate } \\
\text { mofetil, azathioprine, } \\
\text { hydroxychloroquine, } \\
\text { apremilast, cyclosporine, } \\
\text { triamcinolone acetonide } 0.1 \% \text {, } \\
\text { tacrolimus } 0.1 \% \text { ointments }\end{array}$ & $\begin{array}{l}\text { Dupilumab } 600 \mathrm{mg} \text { and } \\
\text { then } 300 \mathrm{mg} \text { every } 2 \\
\text { weeks/every week }\end{array}$ & 9 months & Partial & Conjunctivitis & [5] \\
\hline $6 \mathrm{I} / \mathrm{F}$ & 4 & $\begin{array}{l}\text { Corticosteroids, calcineurin } \\
\text { inhibitors, } \\
\text { hydroxychloroquine, } \\
\text { mycophenolate mofetil }\end{array}$ & $\begin{array}{l}\text { Dupilumab } 600 \mathrm{mg} \text { and } \\
300 \mathrm{mg} \text { every week, } \\
\text { topical therapies }\end{array}$ & 10 months & Partial & None & [4] \\
\hline $76 / M$ & 1.5 & $\begin{array}{l}\text { Corticosteroids, } \\
\text { mycophenolate mofetil }\end{array}$ & $\begin{array}{l}\text { Dupilumab } 600 \mathrm{mg} \text { and } \\
\text { then } 300 \mathrm{mg} \text { every week, } \\
\text { topical therapies }\end{array}$ & 4 months & Partial & $\begin{array}{l}\text { Facial } \\
\text { redness }\end{array}$ & [4] \\
\hline 79/M & 4 & $\begin{array}{l}\text { Corticosteroids, } \\
\text { mycophenolate mofetil, } \\
\text { methotrexate, azathioprine }\end{array}$ & $\begin{array}{l}\text { Dupilumab } 600 \mathrm{mg} \text { and } \\
\text { then } 300 \mathrm{mg} \text { every week, } \\
\text { topical therapies }\end{array}$ & 26 months & Partial & Conjunctivitis & [4] \\
\hline $66 / M$ & 6 & $\begin{array}{l}\text { Corticosteroids, calcineurin } \\
\text { inhibitors, mycophenolate } \\
\text { mofetil }\end{array}$ & $\begin{array}{l}\text { Dupilumab } 600 \mathrm{mg} \text { and } \\
\text { then } 300 \mathrm{mg} \text { every week, } \\
\text { topical therapies }\end{array}$ & 16 months & Partial & None & [4] \\
\hline $49 / M$ & 4 & $\begin{array}{l}\text { Corticosteroids, calcineurin } \\
\text { inhibitors, mycophenolate } \\
\text { mofetil }\end{array}$ & $\begin{array}{l}\text { Dupilumab } 600 \mathrm{mg} \text { and } \\
\text { then } 300 \mathrm{mg} \text { every week, } \\
\text { topical therapies }\end{array}$ & 18 months & Partial & Conjunctivitis & [4] \\
\hline $82 / M$ & 10 & $\begin{array}{l}\text { Topical corticosteroids, } \\
\text { ebastine, hydroxychloroquine, } \\
\text { tripterygium glycoside tablets }\end{array}$ & $\begin{array}{l}\text { Dupilumab } 600 \mathrm{mg} \text { and } \\
\text { then } 300 \mathrm{mg} \text { every week, } \\
\text { calcium, vitamin D, } \\
\text { ebastine, oral } \\
\text { hydroxychloroquine, } \\
\text { topical corticosteroids }\end{array}$ & 16 weeks & Partial & None & [6] \\
\hline
\end{tabular}


strict sun avoidance, topical and systemic corticosteroids, calcineurin inhibitors, azathioprine, cyclosporine, mycophenolate mofetil, hydroxychloroquine, and PUVA therapy. ${ }^{5,9}$ However, these treatments are not so effective in most patients with severe $\mathrm{CAD}$; thus, thalidomide, colostrum-macrophageactivating factor, and biotherapy (tofacitinib and dupilumab) have been proposed to be particularly beneficial in improving outcomes in these cases. ${ }^{4-6,10,11}$ Dupilumab, a monoclonal antibody that targets type 2 helper T-cell (Th2) cytokines, inhibits both IL-4 and IL-13 signaling pathways, decreasing subsequent effector cell function. ${ }^{3}$ Only three previous studies have reported the treatment of seven patients with CAD with dupilumab, ${ }^{4-6}$ as shown in Table 1 . All patients had failed to respond sufficiently to at least one line of previous therapy, such as topical corticosteroids, methotrexate, mycophenolate mofetil, azathioprine, hydroxychloroquine, apremilast, and cyclosporine. After administration of dupilumab (initial dose of $600 \mathrm{mg}$ in the first week and $300 \mathrm{mg}$ every 2 weeks thereafter) alone or with other treatments, these seven patients experienced dramatic improvement. Four patients complained of conjunctivitis and facial redness. Although our patient developed diffuse pigmentation 2 months after dupilumab administration, it remains unclear whether this was caused by dupilumab. Previous studies found that hydroxychloroquine (HCQ)-induced cutaneous pigmentation occurs in 10$30 \%$ patients, most commonly over the shins, face, and palate, after approximately 4 months of treatment. ${ }^{12,13}$ Thus, pigmentation may be caused by HCQ and not by dupilumab. The eight patients presented here support the hypothesis that dramatic clinical improvement was based on dupilumab suppressing CAD reactions. However, its mode of action in the case of $\mathrm{CAD}$ is not fully understood. Rivas and Ullrich $^{14}$ reported that UVB-induced $\mathrm{CD}^{+}, \mathrm{CD}^{+}$, and $\mathrm{CD}^{-}$regulatory $\mathrm{T}$ cells mediate their suppressive effects by releasing the immuneregulatory cytokines IL-4 and IL-10. UV irradiation suppresses antigen presentation to Th1 cells but enhances that to Th2 cells. ${ }^{15}$ It was suggested that dupilumab interacts with the pathogenic cascade of CAD, potentially implicating the role of Th2 in the pathophysiology of CAD. Although the underlying immunological pathways in $\mathrm{CAD}$ and $\mathrm{AD}$ are not the same, they are largely overlapping. ${ }^{16}$ Some research ${ }^{17,18}$ found CAD in some young patients with a history of AD. This may explain why targeting the shared Th2 pathway could reduce CAD severity. Thus, dupilumab may be a therapeutic option for refractory cases where standard therapy modalities are ineffective or contraindicated. More controlled clinical trials are needed to draw any further conclusions.

\section{Ethics Statement}

The authors certify that they have obtained all appropriate patient consent forms. The patient gave written informed consent for publication of clinical information and photographs. No ethical committee approval was required because the data were analyzed in a retrospective manner.

\section{Disclosure}

The authors declare no conflict of interest.

\section{References}

1. Paek SY, Lim HW. Chronic actinic dermatitis. Dermatol Clin. 2014;32:355-361. doi:10.1016/j.det.2014.03.007

2. Ko DY, Choi SH, Ha SM, et al. The clinical severity score of chronic actinic dermatitis correlates with in vivo photoallergic reactions and the immunologic parameters related to a shift towards Th2 immunity from the Th2/Th1 balanced status in patients with chronic actinic dermatitis. Photodermatol Photoimmunol Photomed. 2016;32:199-206. doi:10.1111/phpp.12244

3. Siegfried EC, Bieber T, Simpson EL, et al. Effect of dupilumab on laboratory parameters in adolescents with atopic dermatitis: results from a randomized, placebo-controlled, phase 3 clinical trial. $\mathrm{Am}$ $J$ Clin Dermatol. 2021;22:243-255. doi:10.1007/s40257-02000583-3

4. Patel N, Konda S, Lim HW. Dupilumab for the treatment of chronic actinic dermatitis. Photodermatol Photoimmunol Photomed. 2020;36:398-400. doi:10.1111/phpp.12566

5. Verma L, Pratt M. A case report of therapeutically challenging chronic actinic dermatitis. SAGE Open Med Case Rep. 2019;7:1984523X-2050313X. doi:10.1177/2050313X19845235

6. Chen JC, Lian CH. Chronic actinic dermatitis in an old adult significantly improved by dupilumab. Photodermatol Photoimmunol Photomed. 2021. doi:10.1111/phpp.12731

7. Sidiropoulos M, Deonizio J, Martinez-Escala ME, Gerami P, Guitart J. Chronic actinic dermatitis/actinic reticuloid: a clinicopathologic and immunohistochemical analysis of 37 cases. Am J Dermatopathol. 2014;36(11):875-881. doi:10.1097/DAD.000 0000000000076

8. Dawe RS, Ferguson J. Diagnosis and treatment of chronic actinic dermatitis. Dermatol Ther. 2003;16:45-51. doi:10.1046/j.15298019.2003.01607.x

9. Agar N, Morris S, Russell-Jones R, Hawk J, Whittaker S. Case report of four patients with erythrodermic cutaneous T-cell lymphoma and severe photosensitivity mimicking chronic actinic dermatitis. $\mathrm{Br}$ $J$ Dermatol. 2009;160:698-703. doi:10.1111/j.1365-2133.2008. 08955.x

10. Ichihashi $M$, Nakamura $Y$, Muto $M$, Nishikata $T$, Inui $T$, Uto $Y$. A case of chronic actinic dermatitis that responded completely to treatment with oral colostrum-macrophage-activating factor (colostrum-MAF). Photodermatol Photoimmunol Photomed. 2019;35:290-292. doi:10.1111/phpp.12469

11. Lahouel M, Ben Kahla M, Aounallah A, et al. Severe chronic actinic dermatitis treated successfully with thalidomide. Photodermatol Photoimmunol Photomed. 2020;36:493-495. doi:10.1111/phpp.12588

12. Thakur V, Dalla A, Kumar S, Kumaran MS, Aggarwal D, Radotra BD. Hydroxychloroquine induced cutaneous pigmentation: a unique pattern. Postgrad Med J. 2019;95(1121):169-170. doi:10.1136/postgradmedj-2018-136377

13. Amichai B, Gat A, Grunwald MH. Cutaneous hyperpigmentation during therapy with hydroxychloroquine. J Clin Rheumatol. 2007;13(2):113. doi:10.1097/01.rhu.0000260649.36417.09 
14. Rivas JM, Ullrich SE. The role of IL-4, IL-10, and TNF-alpha in the immune suppression induced by ultraviolet radiation. $J$ Leukoc Biol. 1994;56:769-775. doi:10.1002/jlb.56.6.769

15. Ullrich SE. Does exposure to UV radiation induce a shift to a Th-2-like immune reaction? Photochem Photobiol. 1996;64:254-258.

16. Quatrano NA, Shvartsbeyn M, Meehan SA, Soter NA, Cohen DE. Chronic actinic dermatitis occurring in an adult with atopic dermatitis. Dermatol Online J. 2015;21(12). doi:10.5070/ D32112029546
17. Creamer D, McGregor JM, Hawk JL. Chronic actinic dermatitis occurring in young patients with atopic dermatitis. $\mathrm{Br} J$ Dermatol. 1998;139:1112-1113. doi:10.1046/j.1365-2133.1998.2576c.x

18. Ogboli MI, Rhodes LE. Chronic actinic dermatitis in young atopic dermatitis sufferers. $B r J$ Dermatol. 2000;142:845. doi:10.1046/ j.1365-2133.2000.03457.x

\section{Publish your work in this journal}

Clinical, Cosmetic and Investigational Dermatology is an international, peer-reviewed, open access, online journal that focuses on the latest clinical and experimental research in all aspects of skin disease and cosmetic interventions. This journal is indexed on CAS.
The manuscript management system is completely online and includes a very quick and fair peer-review system, which is all easy to use. Visit http://www.dovepress.com/testimonials.php to read real quotes from published authors. 